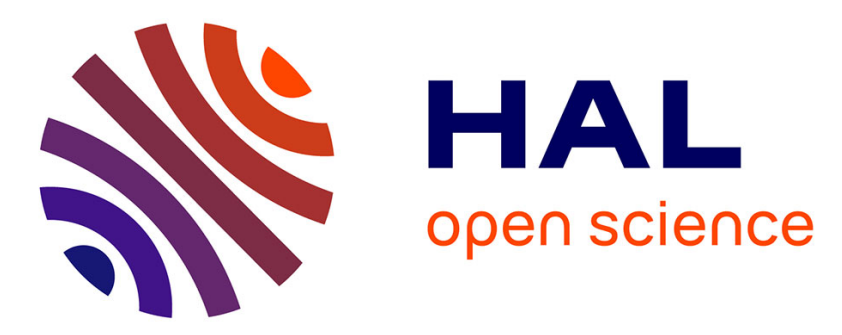

\title{
A three-year time series of mineral dust deposits on the West African margin: Sedimentological and geochemical signatures and implications for interpretation of marine paleo-dust records
}

C. Skonieczny, A. Bory, V. Bout-Roumazeilles, W. Abouchami, S. J. G. Galer, X. Crosta, Aboubacry Diallo, T. Ndiaye

\section{To cite this version:}

C. Skonieczny, A. Bory, V. Bout-Roumazeilles, W. Abouchami, S. J. G. Galer, et al.. A three-year time series of mineral dust deposits on the West African margin: Sedimentological and geochemical signatures and implications for interpretation of marine paleo-dust records. Earth and Planetary Science Letters, 2013, 364, pp.145-156. 10.1016/j.epsl.2012.12.039 . hal-02105633

\section{HAL Id: hal-02105633 \\ https://hal.science/hal-02105633}

Submitted on 28 Jul 2021

HAL is a multi-disciplinary open access archive for the deposit and dissemination of scientific research documents, whether they are published or not. The documents may come from teaching and research institutions in France or abroad, or from public or private research centers.
L'archive ouverte pluridisciplinaire HAL, est destinée au dépôt et à la diffusion de documents scientifiques de niveau recherche, publiés ou non, émanant des établissements d'enseignement et de recherche français ou étrangers, des laboratoires publics ou privés. 


\section{A three-year time series of mineral dust deposits on the West African margin: Sedimentological and geochemical signatures and implications for interpretation of marine paleo-dust records}

C. Skonieczny ${ }^{\mathrm{a},{ }^{*}}$, A. Bory ${ }^{\mathrm{a}}$, V. Bout-Roumazeilles ${ }^{\mathrm{a}}$, W. Abouchami ${ }^{\text {b,c }}$, S.J.G. Galer ${ }^{\mathrm{b}}$, X. Crosta $^{\text {d }}$, A. Diallo ${ }^{\text {e }}$, T. Ndiaye ${ }^{\text {e }}$

${ }^{\text {a} G E O S Y S T E M E S, ~ U M R ~} 8217$ CNRS-Université Lille 1, 59655 Villeneuve d'Ascq, France

${ }^{\mathrm{b}}$ Max Planck Institute for Chemistry, P.O. Box 3060, 55020 Mainz, Germany

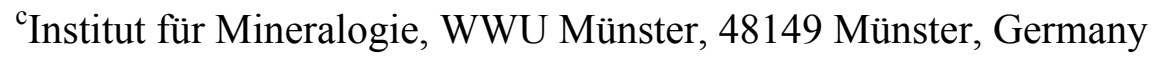

${ }^{\mathrm{d}}$ EPOC, UMR 5805 CNRS-Université Bordeaux 1, 33400 Talence, France

${ }^{\mathrm{e}}$ IRD, US 191 IMAGO, Dakar, Senegal

*Correspondence to: Université Lille 1, GEOSYSTEMES, UMR CNRS 8217, Cité Scientifique Bâtiment SN5, 59655 Villeneuve d'Ascq, France. Tel.: +33320437117; fax: +33320434125 .

E-mail addresses: charlotte.skonieczny@univ-lille1.fr (C. Skonieczny), aloys.bory@univlille1.fr (A. Bory), viviane.bout@univ-lille1.fr (V. Bout-Roumazeilles), wafa.abouchami@mpic.de (W. Abouchami), steve.galer@mpic.de (S.J.G. Galer), x.crosta@univ-bordeaux1.fr (X. Crosta), aboubacry.diallo@ird.fr (A. Diallo), ndthier@yahoo.fr (T. Ndiaye).

\section{Keywords}

Saharan, dust deposition, flux grain size, clay mineralogy, $\mathrm{Sr}$ and $\mathrm{Nd}$ isotopes, AMMA program

\section{Abstract}


Mineral dust deposits in the Northeastern Tropical Atlantic Ocean (NETAO) are an important contribution for reconstructing paleoenvironments and paleoclimates of West Africa. However, the interpretation of the changes in the sedimentological and geochemical characteristics of the dust deposits recorded in the marine sediments from the NETAO remains incomplete. In order to improve our understanding of dust proxies, in particular its mineralogical and geochemical provenance tracers, present-day dust deposition has been monitored at Mbour ( $80 \mathrm{~km}$ south of Dakar) on the Senegalese margin. Here we report a multi- proxy investigation of a unique three-year continuous time series of mineral dust deposits collected at a weekly (or better) temporal resolution over the March 2006-March 2009 period. Mass deposition flux and mean modal grain size display marked but reverse seasonal features, with higher flux during the winter/ spring seasons and coarser grain size mode in summer when flux is minimal, reflecting contrasting transport patterns throughout the year. Similarly, clay mineralogy, the illite/kaolinite ratio in particular, shows seasonal fluctuations, manifesting the latitudinal displacement of the contributing domains of provenance in response to the seasonal migration of the ITCZ position and the associated wind systems. Our three-year record also reveals the occurrence of major deposition events superimposed on the seasonal pattern, generally during the winter/spring dry seasons and most frequently during the month of March. Our study shows that these major events, which contribute a large fraction of the total annual deposition flux, all originate from the western Sahara-Sahel (a major area of emission in the region beside the Bodele Depression, stretching from the Mauritanian and Western Saharan coasts to the Hoggar Mountains). Combined with air mass tri-dimensional back-trajectories and satellite images, the mineralogical and $\mathrm{Sr}-\mathrm{Nd}$ isotopic compositions of these large dust events enable us to identify several mineralogically and geochemically distinct provenance sectors within this vast western area. Unlike the background dust deposits, the ${ }^{87} \mathrm{Sr} /{ }^{86} \mathrm{Sr}$ and the $\varepsilon_{\mathrm{Nd}}$ isotopic signatures of the major dry events closely match that of the NETAO Late Holocene sediments, supporting the hypothesis that these events account for most of the aeolian terrigenous supply reaching the ocean floor. Although this database needs to be expanded, our results already provide useful constraints for the interpretation of the dust proxies' variations in marine sedimentary archives off Mauritania/Senegal in terms of changes in wind regimes and aridity over West Africa.

\section{Introduction}


The Northeastern Tropical Atlantic Ocean (hereinafter NETAO) receives large amounts of mineral dust transported by the atmosphere from the Sahara and Sahel arid and semi-arid regions (Prospero, 1996). In the absence of significant fluvial sediment discharge on the West African margin, these dust inputs represent most of the non-biogenic material reaching the open ocean floor (Kolla et al., 1979). The long-term geological history of these aeolian deposits is well recorded in the marine sediments of the NETAO region (e.g., Matthewson et al., 1995). As dust supplies reflect dryness conditions and wind patterns over the continent, they contribute to document the long-term environmental and climatic changes that have taken place in West Africa throughout the Quaternary and beyond (Rea, 1994). Increased dust fluxes, for instance, have been interpreted as indicative of aridity intensification (Tiedemann et al., 1989; Rea, 1990). Similarly, coarser dust grain sizes have been linked to stronger winds (Sarnthein et al., 1982; Ruddiman, 1997). The ability to use dust records to monitor wind strength is particularly useful, as there is virtually no other tracer available to constrain the vigor of low-latitude atmospheric circulation in paleo-climate reconstructions and models (e.g., Mulitza et al., 2008).

Nonetheless, the interpretation of marine sediment dust records in the NETAO has been limited by the lack of information regarding dust provenance. Although the SaharanSahel region stretches over an area of around 2000-by-4000km2 area at present, and contains numerous distinct high-emission "hot spots" (Goudie and Middleton, 2001; Prospero et al., 2002; Engelstaedter and Washington, 2007a,b), it has been considered as a "single source"' in most paleoclimatic studies. Valuable additional information on shifts in transport systems and the distribution of arid areas over West Africa could certainly be gained if we were able to define more precisely the origin of the dust and its variability over time in paleo-dust records. Specific mineralogical and geochemical intrinsic tracers, which reflect the geological and weathering history of the dust source area, can be analyzed and used for this purpose (Grousset et al., 1998; Bout-Roumazeilles et al., 2007; Colin et al., 2008; Meyer et al., 2011). Provenance can then be inferred by matching the dust signature with those of potential source areas (Grousset and Biscaye, 2005).

There have been several attempts to use radiogenic isotopes ( $\mathrm{Sr}$ and $\mathrm{Nd}$ ), for example, for identifying possible shifts in dust provenance through recent climate transitions (Grousset et al., 1998; Jullien et al., 2007; Cole et al., 2009; Stumpf et al., 2011). These studies have been hindered, however, by the fact that the signature of potential source areas is not well documented. Indeed, there is clearly insufficient data coverage over the Sahara-Sahel region, 
mostly due to the large number of possible dust sources spread over this vast territory (Engelstaedter and Washington, 2007b; Formenti et al., 2011). Previous provenance investigations therefore have relied on data obtained from various types of geological samples (rocks, soils, sediments etc.). How representative these samples are with respect to the dust sources is difficult to assess, however. As a result, inferences obtained from these provenance proxies up until now has been limited.

Additionally, the interpretation of dust records has been hampered by the fact that there is poor understanding also of the wind systems responsible for the dust deposited in the NETAO. One way of improving the interpretation of the paleo- dust records might be to turn to modern deposits reaching the NETAO. The main interest in monitoring current dust deposition in the NETAO region is that information on the contributing source regions and associated wind patterns can be obtained simultaneously from meteorological and remotesensing data. The mineralogical and isotopic signature of the dust obtained in this way can therefore be traced back directly to its region of provenance within West Africa. Another advantage in collecting present-day dust as it reaches the oceanic domain is that these dust samples then also reflect the complex mixing processes that occur between multiple contributing sources during Saharan outbreaks. Such mixing would be difficult to reproduce using the present incomplete database of potential source areas.

Furthermore, it is known that the initial grain size distribution of a source area evolves during deflation, saltation and atmospheric transport, which may modify the mineralogical composition of the dust and thus its isotopic composition (e.g., Dasch, 1969; Mason, 1982; Martin and Withfield, 1983; Schutz and Sebert, 1987; Alfaro et al., 1997; Sabre et al., 1997). Consequently, even reliable data obtained from soils or sediments found in well- identified dust sources may not truly reflect the signature of the airborne fraction emitted from these areas, making it even more difficult to base provenance investigations on source data alone. Using a combination of deposition measurements and atmospheric transport data enables us to circumvent some of these problems and provide some calibration of the proxies, not only in terms of source area complex signatures (likely mixed) but also in terms of transport patterns and their seasonal timing. Although dust emission, transport and deposition patterns observed at present may not offer match past configurations one-to-one, we believe such an approach can provide new insights in the interpretation of the mineralogical and isotopic records in marine sediments. 
We started sampling dust deposits at Mbour ( $80 \mathrm{~km}$ south of Dakar) on the Senegalese margin in 2006 (Skonieczny et al., 2011), as part of the African Multidisciplinary Monsoon Analysis (AMMA) framework (Redelsperger et al., 2006). The sampling site, located near the western tip of West Africa as well as under major corridors for both winter/spring and summer dust outbreaks, is ideally situated for monitoring mineral aerosol inputs as they reach the NETAO. Here, we report a unique three-year time series of weekly mineral dust deposits at Mbour, spanning the spring 2006 to spring 2009 period. Mass fluxes, grain-size, and clay mineralogy measurements were carried out throughout the entire record. This deposition record enables us, for the first time, to document the temporal pattern of dust deposition in this region in response to the changing wind systems through the whole year.

Further, $\mathrm{Sr}$ and $\mathrm{Nd}$ isotope analyses of samples during some of the major deposition events were carried out as well, along with characterization and identification of fresh-water diatoms. Provenance information, inferred from tri-dimensional back-trajectories and satellite images, allows us to assess the efficacy of the proxies measured for identifying provenance and transport systems. Lastly, we discuss the implications that our finding have for the interpretation of the paleo-dust archives retrieved from the NETAO.

\section{Material and methods}

Mineral dust was collected using a CAPYR-type reversed pyramid-shaped PVC collector installed about $8 \mathrm{~m}$ above ground on the rooftop terrace of the IRD-Mbour research building facing the Atlantic Ocean (14²4’38"N; 1657'32"W; Skonieczny et al., 2011). The sampling site was located in a protected ecological center, which is a vegetated area where car traffic is minimal, reducing influence from locally-produced dust. Our collector has the advantage of being made of plastic only, minimizing potential contamination of the dust samples with metals of interest. However, due to its rather poor aerodynamic shape, the original CAPYR-type collector has lower efficiency (up to a mean factor of around three) than other sampling devices (Goossens and Rajot, 2008). For this reason, the $2500 \mathrm{~cm}^{2}$ sampling area was covered with a 1-cm thick honeycomb-like grid in this study in order to reduce wind turbulence within the collector. This adjustment is thought to have minimized post-depositional remobilization, thus improving the collector's efficiency.

Dust deposited in the device was recovered weekly from February 2006 through March 2009 (except during June- October 2006 period) — by thorough rinsing of the collector 
with ultra-pure water-yielding a total of 140 samples. Temporal sampling resolution was increased during major outbreaks (Table 1). The following steps were carried out in clean laboratory facilities. In order to compare our results to those on the carbonate-free fraction of marine sediments, calcium carbonate was dissolved and removed using an acetic acid (HOAc)—sodium acetate buffer at $\mathrm{pH} 4.5$ (Biscaye, 1965). Although some studies have shown that relatively coarse material can be transported over long distances (e.g., Glaccum and Prospero, 1980), modern dust collected over the Atlantic Ocean at the latitude of our sampling site is mainly $<30 \mu \mathrm{m}$ (Grousset et al., 1998; Stuut et al., 2005). Samples were thus wet-sieved at $30 \mu \mathrm{m}$ before subsequent analysis, in order to remove any extraneous large particles of local origin such as vegetation detritus.

Grain size distributions and clay minerals assemblages were determined for the entire time-series, using a Malvern Mastersizer 2000 laser diffractometer and a Bruker D4 Endeavor $\mathrm{X}$-ray diffractometer, respectively. Strontium and neodymium isotope measurements were carried out on a selection of high-flux samples by Thermo Ionization Mass Spectrometry (TIMS) using a ThermoFisher TRITON instrument at the Max-Planck-Institute for Chemistry in Mainz, Germany. Analytical protocols are those described in Skonieczny et al. (2011). ${ }^{87} \mathrm{Sr} /{ }^{86} \mathrm{Sr}$ ratios were normalized to ${ }^{86} \mathrm{Sr} /{ }^{88} \mathrm{Sr}=0.1194$ and replicate measurements of the NIST SRM 987 standard yield an average ${ }^{87} \mathrm{Sr} /{ }^{86} \mathrm{Sr}=0.710264\left(2 \mathrm{SD}=6 \times 10^{-6}, \mathrm{n}=22\right) .{ }^{43} \mathrm{Nd} /{ }^{144} \mathrm{Nd}$ ratios were normalized to ${ }^{146} \mathrm{Nd} /{ }^{144} \mathrm{Nd}=0.7219$ and measurements of La Jolla $\mathrm{Nd}$ standard yielded ${ }^{143} \mathrm{Nd} /{ }^{144} \mathrm{Nd}=0.511844\left(2 \mathrm{SD} 1=6 \times 10^{-6}, \mathrm{n}=15\right)$. The ${ }^{43} \mathrm{Nd} /{ }^{144} \mathrm{Nd}$ ratios are reported as $\varepsilon_{\mathrm{Nd}}$, the relative deviation from the Bulk Silicate Earth (CHUR) ${ }^{43} \mathrm{Nd} /{ }^{144} \mathrm{Nd}$ ratio of 0.512638 in parts per 10000. Carefully monitored analytical blanks were less than $0.1 \%$ of $\mathrm{Sr}$ and $\mathrm{Nd}$ sample yields and therefore considered negligible.

For some of the high-flux samples, diatom species were also identified and counted using an Olympus BX51 phase contrast microscope at University Bordeaux-1, France following procedures described by Rathburn et al. (1997).

Tri-dimensional back-trajectories were calculated using the HYSPLIT model of NOAA. In addition, this study benefited from satellite animations computed using SEVIRI images.

\section{Results and discussion}

\subsection{Seasonal variability in the dust deposition fluxes}


One of the most striking features of our West African margin three-year time series is the marked seasonal variability in the dust deposition. High fluxes ( $80-180 \mathrm{mg} \mathrm{m}^{-2} \mathrm{~d}^{-1}$ ) occur during the winter/spring months (from November to May), peaking in March, while lower much lower fluxes ( $20-30 \mathrm{mg} \mathrm{m}^{-2} \mathrm{~d}^{-1}$ ) are found in the summer and the autumn (from June to October; Fig. 1). In contrast to the flux record, continuous monitoring of atmospheric aerosol optical thickness at our site (hereinafter AOT) suggests that maximal dust transport over Mbour actually occurs during the summer months (June-July) (Leon et al., 2009), assuming that variations in the AOT-which is mostly sensitive the fine fraction of the dust size distribution - largely reflects variations in the total atmospheric dust load. This is consistent with long-term satellite observations showing that the highest atmospheric dust content over the NETAO is during the summer (e.g., Swap et al., 1996). Such an apparent disconnection in this area between the total dust content in the atmospheric column and its imprint at ground level has been documented using dust concentration data - first at Sal, Cape Verde Archipelago (Chiapello et al., 1995), and more recently at Mbour (Leon et al., 2009). This mismatch was shown to be the result of the increasing dust transport altitude between the winter/spring, when the low-level Trade Winds (Harmattan) blow over the continent (i.e., below $3 \mathrm{~km}$ ), and the summer when dust is transported in the Saharan Air Layer (SAL; up to an altitude of $6 \mathrm{~km}$ ) above the Trade Winds, which have largely a marine origin along the African margin at this time of the year (Chiapello et al., 1995; Bory et al., 2002; Leon et al., 2009). This strongly suggests that the dust deposition flux at Mbour is also governed primarily by the dust load in the lower layers of the atmosphere. Actually, there is overall a very good correlation between our dust deposition fluxes and the seasonal trends in PM10 concentrations (i.e., $<10 \mu \mathrm{m}$ particles) during our 2006-2009 survey (Fig. 1; Marticorena et al., 2010). Our deposition flux data therefore support the view that the winter/spring dust transport system over West Africa is the one predominantly affecting the adjacent NETAO. It is difficult to assess how far to the west these conclusions may hold true. However, dust concentration data obtained at Sal Island (Chiapello et al, 1995; Bory et al., 2002), suggest that dust deposition is mainly driven by the Trade Winds at least as far as the Cape Verde Archipelago.

\subsection{Large contribution from major deposition events}

Superimposed on the seasonal patterns, a few major deposition flux events stick out in our time series (see arrows on Fig. 1). During these events, deposition fluxes were enhanced 
by factors ranging from 2 to 8 compared to background seasonal depositional fluxes. Most of these events were recorded during the winter-spring high-deposition flux season, except for one sizable dust fall, which occurred in the summer (Table 1). In each of these two contrasting seasonal contexts, processes leading to the large depositional fluxes were radically different. During the dry winter/spring seasons, no precipitation occurs and aerosols can thus only be removed from the atmosphere by gravitational settling (dry deposition). All through the summer season, on the other hand, large dust events likely result from washing out of the atmospheric column by rainfall (wet deposition), as our site is under the influence of the summer monsoonal regime at this time of the year. In fact, significant precipitation occurs frequently, and our record suggests that some may occasionally reach the altitude at which dust is being transported. Note that low atmospheric layers contain very little dust in comparison to the winter/spring.

Three out of the four major events recorded in the dry winter/ spring seasons took place during the month of March. The most important deposition flux was recorded during the 27-30 March 2008 period, yielding a deposition flux of $1150 \mathrm{mg} \mathrm{m}^{-2} \mathrm{~d}^{-1}$, which should be compared to a mean seasonal background of $0100-150 \mathrm{mg} \mathrm{m}^{-2} \mathrm{~d}^{-1}$. Dust deposited during this single event represented about 12\% of the total 2008 annual flux (Fig. 2). The second most important dry season event occurred between the 4th and 6th of March 2009, with a maximum deposition flux of $465 \mathrm{mg} \mathrm{m}^{-2} \mathrm{~d}^{-1}$. Another notable March depositional event took place during the 7-13 March 2006 period, and has been described in detail separately (Skonieczny et al., 2011). No major spring peak was observed in 2007. On the other hand, the summer of 2007 was marked by an episode of wet deposition lasting 3 weeks (Table 1), representing two thirds of the JJA seasonal yield and about a quarter of the annual deposition (Fig. 2).

Consequently, although winters and springs overall appear to be the seasons when most dust deposition on the West African margin happens, our 2006-2009 time series shows that sporadic events can lead to significant year-to-year variability in the mean seasonal deposition rates (Fig. 2). In addition, our time series strongly suggests that major dust deposition events can account for a significant fraction of the total annual dust deposition to the nearby NETAO, as previously shown for the Mediterranean Sea (Guerzoni et al., 1997).

\subsection{Grain size range and contrasting temporal pattern}


All dust deposits display a well-sorted unimodal grain-size distribution and the average grain-size mode is about $19 \mathrm{~mm}$, which is in the same order as has been reported before in the literature for the NETAO margin (e.g., Stuut et al., 2005). Despite a highfrequency variability in the grain-size mode, this parameter also exhibits a seasonal trend (Fig. 1). Interestingly, coarser material ( $22 \mu \mathrm{m}$ on average) is deposited during the summer low-flux period. The dust deposits collected during the winter/ spring seasons, on the other hand, consist of relatively finer particles, as indicated by a lower mean grain size mode ( 16 $\mu \mathrm{m})$. Material coarser than $10=$ represents about $60 \%$ and almost $80 \%$ of the winter/spring and summer deposits, respectively (Fig. 3). The significant proportion of coarse particles illustrates the interest in monitoring the grain size distribution from dust deposits-and not only from PM10 suspended particulate matter as it is often the case-for the assessment of the impact of the dust on the oceans or for modeling purposes.

Similar seasonal trends in grain size were identified in the ocean water column by Ratmeyer et al. (1999) near the Cape Verde Islands. This somewhat unexpected anticorrelation between flux and grain size can also be explained by the changing altitude of the dust transport throughout the year (Ratmeyer et al., 1999). In fact, during the winter, the low altitude of the dust transport allows the entire grain size spectrum of the transported particles to be found at ground level and therefore to be deposited in our collector (Fig. 4). In summer, by contrast, when major dust layers reach mid-tropospheric altitudes, only the coarser particles have sufficient settling velocities to reach the surface (Fig. 4), while most of the fine fraction is carried within the SAL wind system across the Atlantic Ocean all the way to the Caribbean and beyond (e.g., Prospero and Carlson, 1972; Chiapello et al., 1997). At ground level, these coarser particles likely add to the minor, residual dust load transported by the coastal trade winds, which are northerly during the summer (Karyampudi et al., 1999). As a result, the proportion of large particles deposited at ground level increases, shifting the mean modal sizes to higher values (Figs. 3 and 4). Flux and grain-size time series thus provide consistent temporal patterns, which both seem to reflect the seasonal variation in the altitude of the dust transport system over the NETAO.

\subsection{Temporal variations in the dust clay-mineral composition}

Clay mineralogy can give valuable information on the provenance of mineral dust (see Chamley, 1989; Caquineau et al., 1998; Bout-Roumazeilles et al., 2007). Clay minerals deposited at Mbour throughout the 2006-2009 time period consist mainly of smectite and 
kaolinite with additional contributions from chlorite, illite and palygorskite (see Supplementary material). A seasonal variability in the clay minerals assemblages is discernable throughout the 2006-2009 period studied, as observed in the flux and the grain size record, and best reflected by the illite/kaolinite ratios $(\mathrm{I} / \mathrm{K})$ and palygorskite percentage (Fig. 1). In winter, these two proxies, which exhibit a consistent temporal pattern, display values averaging 0.4-0.6 and o5\%, respectively. By contrast, during the wet summer months, the $\mathrm{I} / \mathrm{K}$ ratio and the palygorskite percentage increase to reach mean values of $0.8-1.2$ and 5$10 \%$, respectively.

In the West African region, the $\mathrm{I} / \mathrm{K}$ ratio-which is not affected by the various fractionation processes that occur during emission and long-range dust transport (Caquineau et al, 1998) - and the abundance of palygorskite, have both been used for assessing the origin of atmospheric dust samples (Singer and Galan, 1984; Chamley, 1989; Caquineau et al., 1998, 2002) as well as of aeolian particles extracted from marine sediments (Bout-Roumazeilles et al., 2007). Indeed, the $\mathrm{I} / \mathrm{K}$ ratio has been shown to decrease largely from North to South throughout the Saharan/Sahelian latitudinal band (Caquineau et al., 1998, 2002), reflecting the increasing efficiency of weathering, favoring the formation of kaolinite, as climate becomes wetter towards the equator (Chamley, 1989). Palygorskite, a fibrous clay mineral characteristic of the sub-arid belt of the northern hemisphere (Singer and Galan, 1984; Chamley, 1989), can be distributed via aeolian transport over long-range distances (CoudéGaussen et al., 1982; Molinaroli, 1996). It is mainly present in the northern part of West Africa, and is particularly abundant in the anti-Atlas Morocco region and in Tunisian loess (Grousset et al., 1992, Avila et al., 1997).

The seasonal changes observed overall in the $\mathrm{I} / \mathrm{K}$ ratio and palygorskite content (Fig. 1), and thus in dust provenance, suggest a latitudinal shift from southern, Sahelian provenance areas in winter to more northern, Saharan sources during the summer months. Such a seasonal feature would be consistent with the northward shift in the ITCZ following the migration of the insolation maxima. In summer, when the ITCZ reaches its highest latitudinal position, the Sahel region is under the rain belt, which increases vegetation cover. Rainfall and vegetation in the Sahel region during this season thus strongly reduce dust emission (Zender and Kwon, 2005). Consequently, the proportion of dust originating from Saharan soils, in which illite and palygorskite are more abundant, becomes more dominant in the dust deposited on the West African margin. Therefore, in summary, the time-series of $\mathrm{I} / \mathrm{K}$ ratio and palygorskite 
percentages record the changing latitude of the source regions supplying dust to the NETAO throughout the year.

\subsection{Provenance of the major deposition events}

Due to their impact on the total annual deposition flux on the West African margin (Fig. 2), major events certainly make up a large fraction of the terrigenous material found in marine sediments off West Africa. It is therefore particularly important to characterize the mineralogical and geochemical/isotopic signatures of such large dust events, and investigate their associated provenance and transport patterns. Unlike minor dust events, massive dust outbreaks also have the advantage of being clearly visible on satellite images, which greatly helps constraining emission and transport mechanisms. For these reasons, additional analyses - $\mathrm{Sr}$ and $\mathrm{Nd}$ isotopic ratios measurements and freshwater diatom identificationwere carried out on some of the major events that occurred during the 2006-2009 sampling period. "Dry" and "wet" major deposition events (Table 1) were distinguished in the following discussion since they clearly involve dissimilar transport mechanisms and deposition processes (see Section 3.2).

\subsubsection{Multi-proxy signatures of dry major deposition events}

Previous analysis of the March 2006 major event including the use of tri-dimensional backtrajectories and SEVIRI satellite images enabled us to typify the mineralogical and $\mathrm{Sr}-\mathrm{Nd}$ isotopic signatures of at least two different source regions supplying dust off West Africa (Skonieczny et al., 2011). Combining back- trajectories with remote sensing data is particularly useful because air mass back-trajectory calculations alone do not provide information on where dust was incorporated along the path of the tracked air masses (Stuut et al., 2005). Satellite images, on the other hand, can provide valuable clues on the contributing source regions, especially during large events when dust plume formation and evolution are often discernible. A similar approach was therefore adopted in the present study for the March 2008 and March 2009 events, the results of which are compiled in Fig. 5a together with those of the March 2006 event. Particularly important is that all spring outbreaks originated from a vast "western" emission area stretching from the Mauritanian and Western Saharan coasts to the Hoggar Mountains as seen by the Total Ozone Mapping Spectrometer (TOMS) (Goudie and Middleton, 2001; Prospero et al., 2002). This region encompasses large parts of Western Sahara, most of Mauritania, northern Mali and south-western Algeria, and includes several 
hot-spots of dust emission (Prospero et al., 2002; Engelstaedter and Washington, 2007a,b). Further, the three case studies support the view that aeolian mineral dust supplied to the West African margin did not originate in the more south-eastern Bodele depression in Chad, although this area has been argued to be the most important dust source in the Saharan region as well as worldwide (Goudie and Middleton, 2001).

It is apparent from Fig. 5a that the three March events swept- up dust from different sectors within the large western TOMS area previously described, and thus also that different source regions contributed to the dust deposited during each event. Interestingly, clay mineral assemblages and $\mathrm{Sr}$ and $\mathrm{Nd}$ isotope ratios measurements reveal that these different provenance sectors have distinct terrigenous signatures (Table 1). Mineralogical and isotopic fingerprints combined with back-trajectories and satellite images (not shown) thus enable us to distinguish some spatial distribution patterns (Fig. 5b).

As has already shown by the long-term seasonal variations, the clay mineralogical composition appears to vary with latitude inside the western TOMS area, but also with longitude: the $\mathrm{I} / \mathrm{K}$ ratio decreases from 2.2 in the northwest Sahara to 0.3 in the southeast subSahara (Table 1 and Fig. 5b). These results are in agreement with earlier observations from Caquineau et al. (2002) based on dust samples collected by air filtration on the Cape Verde archipelago. Similarly, differences in the measured ${ }^{87} \mathrm{Sr} /{ }^{86} \mathrm{Sr}$ ratios and $\varepsilon \mathrm{Nd}$ are observed between samples having air-mass trajectories traceable to northwestern areas and characterized by "older' crustal values, and those derived from regions further to the South and the East within the sub-Saharan/Sahelian band, typified by "younger" isotopic signatures. In fact, the sector of provenance of the March 2008 event, which defines a narrow strip along the coastal region of Mauritania and Western-Sahara, has the most negative $\varepsilon \mathrm{Nd}$ of 15.2 value and a ${ }^{87} \mathrm{Sr} /{ }^{86} \mathrm{Sr}$ of about 0.720 . The 2009 event, as well as the first phase of the large March 2006 outbreak, appears to have started from a region further to the North-East (northern Western Sahara and Mauritania, and possibly southern Morocco), which is associated with slightly more radiogenic ${ }^{87} \mathrm{Sr} /{ }^{86} \mathrm{Sr}$ values (up to 0.721 ) and less negative $\varepsilon \mathrm{Nd}$ (about 13.6). In contrast to these "western" and "northwestern" signatures, dust originating from areas further inland within central Sahara (including eastern Mauritania, northern Mali, southwestern Algeria and possibly areas even further to the East) appear to display less radiogenic ${ }^{87} \mathrm{Sr} /{ }^{86} \mathrm{Sr}$ values (down to 0.717 ) and more radiogenic $\varepsilon \mathrm{Nd}$ (up to 13 ) as shown by the dust deposited during the second phase of the March 2006 outbreak. These isotopic gradients are consistent with the geology of West Africa, characterized by Precambrian 
outcrops in the Western Sahara, which are older than the Phanerozoic terrains found in the “'southeastern'” area (Trauth and Schluter, 2006). However, the isotopic compositions do not support unmixed contributions from the oldest geological terrains found in this area (e.g., Grousset et al., 1998). This is in agreement with the fact that dust sources are generally found in topographic lows where fine sediments from various contributing sources accumulate (Prospero et al., 2002).

The March 2009 event, which was sampled at a higher, daily, temporal resolution, enables us to follow the evolution of the terrigenous signature across a single event (Table 1). The 5-days sequence reveals that ${ }^{87} \mathrm{Sr} /{ }^{86} \mathrm{Sr}$, for instance, did not switch instantly from its initial value ( 0.713$)$ to its most radiogenic value $(0.721)$, but that intermediate values were observed on each side of the peak (Table 1). These rather gradual changes in ${ }^{87} \mathrm{Sr} /{ }^{86} \mathrm{Sr}$ suggest that the dust deposited at Mbour consisted of mixtures of material from different terrains swept along the pathway of the dust plume, including possible regional contributions whose signature is thought to be reflected by the composition of background dust (i.e., dust deposited outside the main events). Our record thus highlights that the terrigenous signature of the dust deposited on the West African margin in a single episode has multiple source areas contributing, which are activated along the path of the corresponding outbreak. However, because of our high temporal resolution of sampling during all three March outbreaks studied, signature mixings was minimized, enabling us to get as close as possible to the different " "pure'” contributing end-members.

\subsubsection{A single but significant wet deposition event}

Deposition fluxes during the two wet seasons investigated (2007 and 2008) were generally much lower than during the dry season, except for a 3-week period in July 2007 (spanning July 12 to August 2) when considerable wet deposition occurred (mean deposition flux: $500 \mathrm{mg} \mathrm{m}^{-2} \mathrm{~d}^{-1}$ ). In accordance with the high altitude of the dust transport over the summer, PM10 dust concentrations at ground level (Fig. 1) were very low all through this three weeks period. Mineral dust deposited during this time period must therefore have been scavenged from atmospheric layers high up by precipitation. This idea is supported by a sharp drop in the grain-size mode, reaching 14 = throughout the event (Table 1 and Fig. 3), which contrasts with the summer background mode of about $22 \mu \mathrm{m}$. This is also consistent with tridimensional back trajectories calculated at altitudes of 400 and $4500 \mathrm{~m}$ (Fig. 6a and b). These 4-days back-trajectories confirm that air masses reaching Mbour at low altitude came from 
the ocean (Fig. 6a), and cannot therefore account for any dust deposited at all. Conversely, at the altitude typical of the SAL $(4500 \mathrm{~m})$, back-trajectories show that air masses had a Saharan-Sahelian origin. Back trajectories indicate an average E-W pathway over West Africa prior to attaining the vertical position over Mbour.

The relatively uniform mineralogical composition of the three subsequent weekly wet deposits, with an $\mathrm{I} / \mathrm{K}$ of 0.6 and also a narrow range in ${ }^{87} \mathrm{Sr} /{ }^{86} \mathrm{Sr}(0.7158-0.7164)$, suggests intense dust mixing before reaching the West African margin throughout July 2007. Alternatively, this could also imply that a similar process of dust generation, transport and deposition originating from a same provenance area-distinct from those identified in the spring season-operated repeatedly during this three-week period. However, unlike during the winter/spring seasons, it is not possible to infer accurate provenance information from back trajectories at this time of the year. In fact, during the summer, dust is known to be uplifted rapidly to high atmospheric levels over the Sahara, and in particular when the Harmattan flux meets the Monsoonal flux creating high turbulence and thermal convection (e.g., Engelstaedter and Washington, 2007a). Such features are not captured well by the HYSPLIT model, making it difficult to know, exactly, where dust was injected in the easterly flow over West Africa. Nevertheless, the abundance of the diatoms Aulacoseira Gotzeana, in comparison with the major dry deposition events, is very important, and implies a different origin for the dust during this unique wet event.

In any case, this particular July 2007 episode suggests that occasional precipitations events could lead to important dust deposition at this time of the year on the West African margin. This occurs despite the fact that during the summer, elevated dust transport goes nearly undetected at ground level, as shown by atmospheric concentration measurements (Chiapello et al., 1995; Leon et al., 2009; Marticorena et al., 2010). Such observations may thus have important implications for our understanding of the annual deposition cycle on the West African margin, as well as our interpretation of the marine sedimentary paleo-records off the coast. The spatial extent of such events, and whether or not the precipitation systems were restricted to the continental margin or were also offshore, remains to be further investigated.

\section{Implications and conclusions}

\subsection{Present-day dust deposition estimates in the NETAO}


Present-day dust deposition estimates in the NETAO are poorly constrained due to the paucity of deposition flux data, which are virtually non-existent or isolated and whose significance is thus difficult to assess. Although such deposition data and joint grain size distributions are essential for atmospheric transport model validation, and for the assessment of the impact of dust on ocean biogeochemistry, there has been comparatively little effort devoted to carrying out long-term direct measurements of the dust deposition to the oceans. This is probably due to the fact that it has always been a challenge (1) to measure vertical fluxes, since even better designed instruments have variable collection efficiencies, and (2) to keep the appropriate equipment going and maintained for long periods of time, especially at sea or in remote arid locations. The best deposition estimates have there- fore relied on indirect measurements, such as dust concentration in the atmosphere or sediment trap data from the water column (e.g., Prospero, 1996; Ratmeyer et al., 1999).

Our time series of weekly deposits collected at Mbour, which includes two continuous years of measurements (2007 and 2008), enables us to provide an estimate of present-day yearly average Saharan deposition flux to this area of the West African margin. Estimated deposition fluxes calculated for the years 2007 and 2008 are about 44.6 and $36.7 \mathrm{~g} \mathrm{~m} 2 \mathrm{yr} 1$, respectively (Fig. 2). These measurements are remarkably close to fluxes recorded by marine sediment traps deployed near the Canary Islands, the Cap Blanc and the Cape Verde Islands, considering the large uncertainties on both our estimates (see Methods) and those derived from sediment traps (average lithogenic fluxes $20 \mathrm{~g} \mathrm{~m} 2$ yr 1; e.g., Jickells et al., 1996; Fischer et al., 1996; Ratmeyer et al., 1999; Bory and Newton, 2000). The fact that our averages are larger (within a factor of two) than estimates derived from water column measurements is consistent with the fact that dust fluxes decrease westward, as distances from the aeolian African dust sources increase.

Annual "ballpark" deposition fluxes obtained by models for this region are also of the same order of magnitude as our flux measurements, especially considering that the latter should be regarded as lower limits on present-day fluxes (e.g., Prospero, 1996, Duce and Tindale, 1991; Tegen and Fung, 1995; Mahowald et al., 1999; Kohfeld and Harrison, 2001; Mahowald et al., 2011). The deposition flux recorded at Mbour at present exhibits, as has been noted, a marked seasonal variability. In particular, according to our 2006-2009 record, winters and springs appear to be the seasons during which dust deposition in the NETAO is at its highest (Figs. 1 and 2). This feature, however, is not always correctly reproduced by dust 
transport models. Such a mismatch underscores the importance of undertaking longer time series of direct flux measurements to help constrain the parameterizations of the models.

\subsection{Imprint of the Saharan dust Sr and Nd isotopic signature in the NETAO's sediments}

It is interesting to see how the present-day dust signatures we obtained during large dust outbreaks over the 2006-2009 period, along with those of lesser events, compare with those found in the terrigenous fraction of Late Holocene marine sediments from the NETAO, i.e., deposited during a climate configuration very similar to that of today. Such a comparison enables us to test some of the inferences we have made based upon our modern time-series at Mbour.

Measured ${ }^{87} \mathrm{Sr} /{ }^{86} \mathrm{Sr}$ ratios and $\varepsilon_{\mathrm{Nd}}$ in NETAO Late Holocene sediments lying between the Cape Verde and the Canary Islands - taking similar size fractions $(<30-40 \mu \mathrm{m})$ of the carbonate-free "terrigenous" fraction-range from 0.718 to 0.722 and around 12 to 15.7 , respectively (Grousset et al., 1998; Cole et al., 2009). While the $\varepsilon_{\mathrm{Nd}}$ of these core-top sediments seem more radiogenic overall near the Mauritanian mar- gin, the ${ }^{87} \mathrm{Sr} /{ }^{86} \mathrm{Sr}$ ratio distribution in the NETAO margin does not display any notable pattern (Grousset et al., 1998).

Fig. 7 is a plot of the $\varepsilon_{\mathrm{Nd}}$ versus ${ }^{87} \mathrm{Sr} /{ }^{86} \mathrm{Sr}$ ratios for our Mbour dust deposits together with sediment core-top data available from the literature. Dust deposited during the major spring outbreaks at Mbour have the most radiogenic ${ }^{87} \mathrm{Sr} /{ }^{86} \mathrm{Sr}$ ratios of our three-year time series, and these data overlap that of the isotopic domain defined by NETAO Late Holocene sediments. In contrast to the dust deposited during the large outbreaks, the Sr isotopic compositions of the background dust at Mbour are not evident in the marine sediments at all, despite the fact that these deposits represent a sizeable fraction of the winter/spring flux at Mbour. Interestingly, the fairly homogenous isotopic signature of the major wet deposition event recorded in July 2007 also appears to be absent in marine surface sediment data.

These observations support the view that sporadic winter/ spring major dust events constitute most of the dust supply to the deep-sea sediments off the West African margin. Further, since the agreement is good between the ${ }^{87} \mathrm{Sr} /{ }^{86} \mathrm{Sr}$ ratios and $\varepsilon_{\mathrm{Nd}}$ of dust deposited at present and dust in marine archives, it shows that this isotopic signal is well preserved and can be extracted easily from NETAO marine sediments. These results also demonstrate that the regional background signal seen presently on the Senegalese margin is not impacting the 
offshore bottom sediments of the NETAO. Similarly, assuming that the isotopic signature of the only wet event recorded is representative of the "wet deposition" signature, wet deposition events may be more important in terms of flux on the West African margin than they are off shore. This inference is consistent with monsoonal precipitations, whereby it is the intrusion of humid air masses into the continent that is driving condensation and rain. In addition, the ITCZ shows a southward inflexion over the ocean, suggesting that any monsoonal precipitations over the ocean would likely occur further to the South.

\subsection{Implications for the interpretation of the paleo-dust records in the NETAO}

The dust records presented here will need to be augmented. Nonetheless, our threeyear time series already provides some important clues for interpreting terrigenous signals in longer- term NETAO marine sedimentary records. First, as discussed above, our deposition flux record supports the interpretation that aeolian deposits off Mauritania/Senegal primarily reflect large dust outbreaks transported at low atmospheric levels within the continental Trades (i.e., the Harmattan) and deposited by gravitational settling. This appears to be well demonstrated for the Late Holocene, at least, as shown by the good agreement between the ${ }^{87} \mathrm{Sr} /{ }^{86} \mathrm{Sr}$ of present-day dust deposited at Mbour during large outbreaks and that of core-top sediments.

This finding has implications for the provenance of the mineral particles deposited in the NETAO. Our data suggest that the dust presently deposited on the Senegalese margin is derived mainly from the Western Sahara/Mauritania/northern Mali/southern- Algeria areas, in agreement with the main direction of the north- easterly Trade Winds. This domain of provenance encompasses more or less the dust "hot spots" identified in TOMS imagery within the western Sahara/Sahel region. Although changes in environmental conditions in West Africa may have switched off some of the sources that are active today and allowed others to contribute, this geographical province of West Africa should nonetheless be regarded as the most likely source region by far for the dust found in the NETAO sedimentary archives.

Second, the seasonal variability in clay mineralogy and grain size distribution during our three-year time series offers additional insights into the interpretation of these tracers in marine sediments. The fact that the $\mathrm{I} / \mathrm{K}$ ratio, in particular, appears to reflect the seasonal 
migration of the ITCZ at present suggests that this ratio could be a useful indicator of variations of the latitudinal position of the ITCZ over longer time scales in paleo-dust records.

The observed increase in the grain-size mode of the particles deposited on the margin during the summer, when dust is transported at high altitude within the SAL, may have implications for our interpretation of grain size variability in marine sediments as well. Even if it is likely that grain size variations predominantly reflect changes in the strength of the Trade Winds - which, as we have seen, deliver most of the dust to the NETAO_, modulation of the modal grain size might also be caused by changes in the relative contributions from the two prevailing wind systems. Increased summer transport combined with a decreasing influence of the Trade Winds, for example, would likely result in a shift toward coarser grain sizes in marine records. The possible removal of high-altitude dust by precipitation, which was encountered on one occasion during our three- year survey on the Senegalese coast, may potentially also have major implications regarding which transport system controls the aeolian sedimentation. For that matter, future investigations should clearly seek to establish whether such wet events may (or not) be significant for offshore deposition.

The $\mathrm{Sr}$ and $\mathrm{Nd}$ isotopic composition of the major dust events during 2006-2009 exhibit limited variation. Nevertheless, we are still able to resolve isotopic signatures of distinct sectors of provenance within the large Western Sahara/Mauritania/Mali/ SouthernAlgeria area (Fig. 5b). These are, first, a westernmost sector (including coastal Mauritania and Western-Sahara) associated with the most negative $\varepsilon_{\mathrm{Nd}}$ values, down to around 15.2, and with ${ }^{87} \mathrm{Sr} /{ }^{86} \mathrm{Sr}$ of 0.720 ; a northwestern sector (including mainly northern Western Sahara and Mauritania) showing slightly more radiogenic ${ }^{87} \mathrm{Sr} /{ }^{86} \mathrm{Sr}$ values (up to 0.721 ) and less negative $\varepsilon_{\mathrm{Nd}}$ (around 13.6); a more inland, southeastern sector (including eastern Mauritania, northern Mali, southwestern Algeria and possibly areas even further to the East in central Sahara) coupled with younger isotopic signatures $\left({ }^{87} \mathrm{Sr} /{ }^{86} \mathrm{Sr}\right.$ values down to 0.717 and $\varepsilon_{\mathrm{Nd}}$ up to 13) contrasting with the "coastal" and "northwestern" signatures.

This mineralogical and isotopic time series needs to be expanded at our site in Mbour. Ideally, other sampling sites along the West Africa margin will be required as well, in order to capture fully the characteristics of the "Saharan" dust plumes in space and time as they unfold, and thus the signatures of the numerous source areas contributing to the dust deposited at present in the NETAO. The dataset obtained thus far from Mbour is promising in this regard, and is already helpful in interpreting mineralogical and geochemical/isotopic 
archives in offshore marine sediments in terms of paleo-environmental changes over West Africa.

It is expected, of course, that the current climatic setting in Northern Africa differs from earlier configurations, and it is therefore possible that some other sources (whose signatures are yet to be identified) were actively contributing dust in the past. Nevertheless, the isotopic and mineralogical signatures of present-day deposits, such as our Mbour time series, are a key element for deciphering paleo-dust archives, even if climatic conditions and dust (and/or other terrigenous) sources have changed over time. In fact, un-matching signatures might in this case help also in that they will then allow excluding provenance from source areas supplying dust to the NETAO at present. Our three-year record highlights the need for pursuing longer times series of present-day of dust deposition on the West African margin, in order to further our understanding of the present-day dust cycle as well as of how this is imprinted in off-shore marine sedimentary archives.

\section{Acknowledgments}

We thank the AMMA International Scientific Group. Detailed information on AMMA scientific coordination and their sources of funding is available at http://www.ammainternational.org. We are indebted to the IRD-Senegal for granting us access to its Mbour facilities and for technical and logistical support. We gratefully thank all members of the AERONET group, in particular Philippe Goloub and Didier Tanré of LOA from the French part of this program (PHOTONS), for operation of the Mbour (Dakar) site. We would like to acknowledge Claire Bassoullet and Celine Liorzou of IUEM, Ingrid Raczek, Gerlinde Borngässer and Heinz Feldmann of MPI for their precious assistance in the clean lab and with the TIMS, Louis Gonzalez of LOA for most useful SEVIRI satellite images, Béatrice Marticorena of LISA for kindly providing TEOM data. The authors gratefully acknowledge the NOAA Air Resources Laboratory (ARL) for the provision of the HYSPLIT transport and dispersion model and/or READY website (http://www.arl.noaa.gov/ready.php) used in this publication. The authors would like to gratefully acknowledge the three anonymous reviewers as well as the editor G. Henderson for their suggestions which helped to improve the final manuscript.

\section{Appendix A. Supporting information}


Supplementary data associated with this article can be found in the online version at http://dx.doi.org/10.1016/j.epsl.2012.12.039.

\section{References}

Alfaro, S.C., Gaudichet, A., Gomes, L., Maillé, M., 1997. Modeling the size distribution of a soil-aerosol produced by sandblasting. J. Geophys. Res. 102 (D10), 11239-11249.

Avila, A., Queralt Mitjans, I., Alarcon, M., 1997. Mineralogical composition of African dust delivered by red rains over northeastern Spain. J. Geophys. Res.-Atmos. 102 (D18), 2197721996.

Biscaye, P.E., 1965. Mineralogy and sedimentation of recent deep-sea clay in the Atlantic Ocean and adjacent seas and oceans. Geol. Soc. Am. Bull. 76, 803-832. http://dx.doi.org/10.1130/0016-7606(1965)76[803:MASORD] 2.0.CO;2.

Bory, A.J.M., Newton, P.P., 2000. Transport of airborne lithogenic material down through the water column in two contrasting regions of the eastern sub- tropical North Atlantic Ocean. Global Biogeochem. Cycles 14 (1), 297-315.

Bory, A., Dulac, F., Moulin, C., Chiapello, I., Newton, P.P., Guelle, W., Lambert, C.E., Bergametti, G., 2002. Atmospheric and oceanic dust fluxes in the northeastern tropical Atlantic Ocean: how close a coupling? Ann. Geophys. 20 (12), 2067-2076.

Bout-Roumazeilles, V., Combourieu Nebout, N.C., Peyron, O., Cortijo, E., Landais, A., Masson-Delmotte, V., 2007. Connection between South Mediterranean climate and North African atmospheric circulation during the last 50,000 yr BP North Atlantic cold events. Quat. Sci. Rev. 26 (25-28), 3197-3215.

Caquineau, S., Gaudichet, A., Gomes, L., Magonthier, M.C., Chatenet, B., 1998. Saharan dust: clay ratio as a relevant tracer to assess the origin of soil-derived aerosols. Geophys. Res. Lett. 25 (7), 983-986.

Caquineau, S., Gaudichet, A., Gomes, L., Legrand, M., 2002. Mineralogy of Saharan dust transported over northwestern tropical Atlantic Ocean in relation to source regions. J. Geophys. Res. 107 (D15), 4251.

Chamley, H., 1989. Clay Sedimentology. Springer, Berlin.

Chiapello, I., Bergametti, G., Gomes, L., Chatenet, B., Dulac, F., Pimenta, J., Suares, 
E.S., 1995. An Additional low layer transport of Sahelian and Saharan dust over the NorthEastern tropical Atlantic. Geophys. Res. Lett. 22 (23), 3191-3194.

Chiapello, I., Bergametti, G., Chatenet, B., Bousquet, P., Dulac, F., Soares, E.S., 1997. Origins of African dust transported over the northeastern tropical Atlantic. J. Geophys. Res. Atmos. 102 (D12), 13701-13709.

Cole, J.M., Goldstein, S.L., Demenocal, P.B., Hemming, S.R., Grousset, F.E., 2009.

Contrasting compositions of Saharan dust in the eastern Atlantic Ocean during the last deglaciation and African Humid Period. Earth Planet. Sci. Lett. 278 (3-4), 257-266.

Colin, C., Siani, G., Seguenia, F., Blamart, D., Giunta, S., Suc, J.-P., Liu, Z., Frank, N., Briqueu, L., 2008. Reconstruction of Northern African monsoon between 6.2 and 4.9 Ma and possible relationships with Late Miocene events. C. Re. Geosci. 340 (11), 749-760.

Coudé-Gaussen, G., Hillaire-Marcel, C., Rognon, P., 1982. Origine et évolution pédologique des fractions carbonatées dans les loess des Matmata (Sud- Tunisien) d'après leurs teneurs en 13C et 18O. C. R. Acad. Sci. Paris 295, 939-942.

Dasch, E.J., 1969. Strontium Isotopes in Weathering Profiles, Deep-sea sediments and Sedimentary Rocks. Geochim. Cosmochim. Acta 33 (12), 1521-1552. Duce, R.A., Tindale, N.W., 1991. Atmospheric transport of iron and its deposition in the ocean. Limnol. Oceanogr. $36(8), 1715-1726$.

Engelstaedter, S., Washington, R., 2007a. Atmospheric controls on the annual cycle of North African dust. J. Geophys. Res.- Atmos. 112 (D3).

Engelstaedter, S., Washington, R., 2007b. Temporal controls on global dust emissions: the role of surface gustiness. Geophys. Res. Lett. 34 (15).

Fischer, G., Donner, B., Ratmeyer, V., Davenport, R., Wefer, G., 1996. Distinct year- to-year particle flux variations off Cape Blanc during 1988-1991: relation to d180-deduced seasurface temperatures and trade winds. J. Mar. Res. 54, 73-98.

Formenti, P., Schutz, L., Balkanski, Y., Desboeufs, K., Ebert, M., Kandler, K., Petzold, A., Scheuvens, D., Weinbruch, S., Zhang, D., 2011. Recent progress in understanding physical and chemical properties of African and Asian mineral dust. Atmos. Chem. Phys. 11 (16), 8231-8256. 
Glaccum, R.A., Prospero, J.M., 1980. Saharan aerosols over the tropical North Atlantic mineralogy. Mar. Geol. 37, 295-321, http://dx.doi.org/10.1016/0025- 3227(80)90107-3.

Goossens, D., Rajot, J.L., 2008. Techniques to measure the dry aeolian deposition of dust in arid and semiarid landscape: A comparative study in West Niger. Earth Surf. Processes Landforms 33, 178-195, http://dx.doi.org/10.1002/esp.1533.

Goudie, A.S., Middleton, N.J., 2001. Saharan dust storms: nature and consequences. EarthSci. Rev. 56 (1-4), 179-204.

Grousset, F.E., Biscaye, P.E., 2005. Tracing dust sources and transport patterns using Sr, Nd and $\mathrm{Pb}$ isotopes. Chem. Geol. 222 (3-4), 149-167.

Grousset, F.E., Rognon, P., Coudé-Gaussen, G., Pedemay, P., 1992. Origins of Peri- Saharan dust deposits traced by their $\mathrm{Nd}$ and $\mathrm{Sr}$ isotopic composition. Palaeogeogr. Palaeoclimatol. Palaeoecol. 93 (3-4), 203-212.

Grousset, F.E., Parra, M., Bory, A., Martinez, P., Bertrand, P., Shimmield, G., Ellam, R.M., 1998. Saharan wind regimes traced by the $\mathrm{Sr}-\mathrm{Nd}$ isotopic composition of subtropical Atlantic sediments: last Glacial maximum vs. today. Quat. Sci. Rev. 17 (4-5), 395-409.

Guerzoni, S., Molinaroli, E., Chester, R., 1997. Saharan dust inputs to the western Mediterranean Sea: depositional patterns, geochemistry and sedimentological implications. Deep Sea Res. Part I 44 (3-4), 631-654.

Jickells, T.D., Newton, P.P., King, P., Lampitt, R.S., Boutle, C., 1996. A comparison of sediment trap records of particle fluxes from 191 to $481 \mathrm{~N}$ in the northeast Atlantic and their relation to surface water productivity. Deep Sea Res. Part I 43, 971-986.

Jullien, E., Grousset, F., Malaize, B., Duprat, J., Sanchez-Goni, M.F., Eynaud, F., Charlier, K., Schneider, R., Bory, A., Bout-Roumazeilles, V., Flores, J.A., 2007. Low-latitude “'dusty events” vs. high-latitude “icy Heinrich events”. Quat. Res. 68 (3), 379-386.

Karyampudi, M.V., Palm, S.P., Reagen, J.A., Fang, H., Grant, W.B., Hoff, R.M., Moulin, C., Pierce, H.F., Torres, O., Browell, E.V., 1999. Validation of the Saharan Dust Plume Conceptual Model using Lidar, Meteosat, and Ecmwf Data. Bull. Am. Meteorol. Soc. 80 (6), 1045-1076.

Kohfeld, K.E., Harrison, S.P., 2001. DIRTMAP: the geological record of dust. Earth Sci. Rev. $54(1-3), 81-114$. 
Kolla, V., Biscaye, P.E., Hanley, A.F., 1979. Distribution of Quartz in late quaternary Atlantic sediments in relation to climate. Quat. Res. 11 (2), 261-277.

Leon, J.F., Derimian, Y., Chiapello, I., Tanre, D., Podvin, T., Chatenet, B., Diallo, A., Deroo, C., 2009. Aerosol vertical distribution and optical properties over M'Bour (16.96 degrees W; 14.39 degrees N), Senegal from 2006 to 2008. Atmos. Chem. Phys. 9 (23), 9249-9261.

Mahowald, N., Kohfeld, K., Hansson, M., Balkanski, Y., Harrison, S.P., Prentice, I.C., Schulz, M., Rodhe, H., 1999. Dust sources and deposition during the last glacial maximum and current climate: a comparison of model results with paleodata from ice cores and marine sediments. J. Geophys. Res._Atmos. 104 (D13), 15895-15916.

Mahowald, N., Albani, S., Engelstaedter, S., Winckler, G., Goman, M., 2011. Model insight into glacial-interglacial paleodust records. Quat. Sci. Rev. 30 (7-8), 832-854.

Marticorena, B., Chatenet, B., Rajot, J.L., Traore, S., Coulibaly, M., Diallo, A., Kone, I., Maman, A., Diaye, T.N., Zakou, A., 2010. Temporal variability of mineral dust concentrations over West Africa: analyses of a pluriannual monitoring from the AMMA Sahelian Dust Transect. Atmos. Chem. Phys. 10 (18), 8899-8915.

Martin, J.-M., Withfield, M., 1983. The significance of the river input of chemical elements to the ocean, in Trace Metals. In: Wong, C.S., et al. (Eds.), Sea Water. Plenum, New York, pp. $265-296$.

Mason, B., 1982. Principles of Geochemistry, 3rd ed. John Wiley, New York, pp. 310.

Matthewson, A.P., Shimmield, G.B., Kroon, D., Fallick, A.E., 1995. A 300-kyr highresolution aridity record of the North-African Continent. Paleoceanography 10 (3), 677-692.

Meyer, I., Davies, G.R., Stuut, J.B.W., 2011. Grain size control on Sr-Nd isotope provenance studies and impact on paleoclimate reconstructions: an example from deep-sea sediments offshore NW Africa. Geochem. Geophys. Geosyst. 12 (3), Q03005.

Molinaroli, E., 1996. Mineralogical characterization of Saharan dust with a view to its final destination in Mediterranean sediments. In: Guerzoni, S., Chester, R. (Eds.), The Impact of Desert Dust Across the Mediterranean. Kluwer Academic, Dordrecht, pp. 153-162.

Mulitza, S., Prange, M., Stuut, J.-B., Zabel, M., Von Dobeneck, T., Itambi, A.C., Nizou, J., Schulz, M., Wefer, G., 2008. Sahel megadroughts triggered by glacial slowdowns of Atlantic meridional overturning. Paleoceanography 23 (4), PA4206. 
Prospero, J.M., 1996. Saharan dust transport over the North Atlantic Ocean and Mediterranean: an overview. In: Guerzoni, S., Chester, R. (Eds.), The Impact of Desert Dust from Northern Africa across the Mediterranean. Kluwer Academic Publisher, Oristano (Sardinia), pp. 133-151.

Prospero, J.M., Carlson, T.N., 1972. Vertical and areal distribution of Saharan dust over western equatorial North-Atlantic Ocean. J. Geophys. Res. 77 (27), 5255-5265.

Prospero, J.M., Ginoux, P., Torres, O., Nicholson, S.E., Gill, T.E., 2002. Environmental characterization of global sources of atmospheric soil dust identified with the Nimbus 7 Total Ozone Mapping Spectrometer (TOMS) absorbing aerosol product. Rev. Geophys. 40, 1.

Rathburn, A.E., Pichon, J.J., Ayress, M.A., DeDeckker, P., 1997. Microfossil and stableisotope evidence for changes in Late Holocene palaeoproductivity and palaeoceanographic conditions in the Prydz Bay region of Antarctica. Palaeo- geogr. Palaeoclimatol. Palaeoecol. $131(3-4), 485-510$.

Ratmeyer, V., Balzer, W., Bergametti, G., Chiapello, I., Fischer, G., Wyputta, U., 1999. Seasonal impact of mineral dust on deep-ocean particle flux in the eastern subtropical Atlantic Ocean. Mar. Geol. 159 (1-4), 241-252.

Rea, D.K., 1990. Aspects of atmospheric circulation: the Late Pleistocene 0-950,000 yr. records of eolian deposition in the Pacific Ocean. Palaeogeogr. Plaeoclimatol. Palaeoecol. 78, $217-227$.

Rea, D.K., 1994. The Paleoclimatic record provided by Eolian deposition in the deep-seathe Geologic History of Wind. Rev. Geophys. 32 (2), 159-195.

Redelsperger, J., Thorncroft, D., Diedhiou, A., Lebel, T., Parker, D., Polcher, J., 2006. African Monsoon Multidisciplinary Analysis: An international research project and field campaign. Bull. Am. Meteorol. Soc. 87, 1739-1746, http://dx.doi.org/ 10.1175/BAMS-87-121739 .

Ruddiman, W.F., 1997. Tropical Atlantic terrigenous fluxes since 25,000 yrs BP. Mar. Geol. $136(3-4), 189-207$.

Sabre, M., Lopez, M.V., Alfaro, S.C., Rajot, J.L., Gomes, L., 1997. Characterization of the fine dust particle production process by wind erosion for two types of bare soil surface. In: Skidmore, E.L., Tatarko, J. (Eds.), Wind Erosion-An International Symposium. USDA-ARS Wind Erosion Res. Unit. 
Sarnthein, M., Thiede, J., Pflaumann, U., Erlenkeuser, H., Futterer, D., Koopmann, B., Lange, H., Seibold, E., 1982. Atmospheric and oceanic circulation patterns off Northwest Africa during the past 25 million years. In: Rad, U., Hinz, K., Sarnthein, M., Seibold, E. (Eds.), Geology of the Northwest African Continental Margin. Springer, Berlin, pp. 545-604.

Schutz,L.,Sebert,M.,1987.Mineralaerosolsandsourceidentification.J.Aerosol. Sci. 18, 1-10.

Singer, A., Galan, E., 1984. Palygorskite-Sepiolite. Occurences, Genesis and Uses. Developments in Sedimentology. Elsevier, Amsterdam.

Skonieczny, C., Bory, A., Bout-Roumazeilles, V., Abouchami, W., Galer, S.J.G., Crosta, X., Stuut, J.B., Meyer, I., Chiapello, I., Podvin, T., Chatenet, B., Diallo, A., Ndiaye, T., 2011. The 7-13 March 2006 major Saharan outbreak: multiproxy characterization of mineral dust deposited on the West African margin. J. Geophys. Res.- Atmos. 116.

Stumpf, R., Frank, M., Schonfeld, J., Haley, B.A., 2011. Climatically driven changes in sediment supply on the SW Iberian shelf since the Last Glacial Maximum. Earth Planet. Sci. Lett. 312 (1-2), 80-90.

Stuut, J.B., Zabel, M., Ratmeyer, V., Helmke, P., Schefuss, E., Lavik, G., Schneider, R., 2005. Provenance of present-day eolian dust collected off NW Africa. J. Geophys. Res.Atmos. 110 (D4).

Swap, R., Ulanski, S., Cobbett, M., Garstang, M., 1996. Temporal and spatial characteristics of Saharan dust outbreaks. J. Geophys. Res.-Atmos. 101 (D2), 4205-4220.

Tegen, I., Fung, I., 1995. Contribution to the atmospheric mineral aerosol load from landsurface modification. J. Geophys. Res.-Atmos. 100 (D9), 18707-18726. Tiedemann, R., Sarnthein, M., Stein, R., 1989. Climatic changes in the western Sahara: aeolo-marine sediment record of the last 8 million years (site 657-661). Proc. Ocean Drill. Prog. Sci. Results 108, 241-277.

Trauth, M.H., Schlu ter, T., 2006. Geological Atlas of Africa: With Notes on Stratigraphy, Tectonics, Economic Geology, Geohazards and Geosites of Each Country. Springer, Berlin, pp. 272.

Zender, C.S., Kwon, E.Y., 2005. Regional contrasts in dust emission responses to climate. J. Geophys. Res.-Atmos. 110 (D13). 


\section{Figure captions}
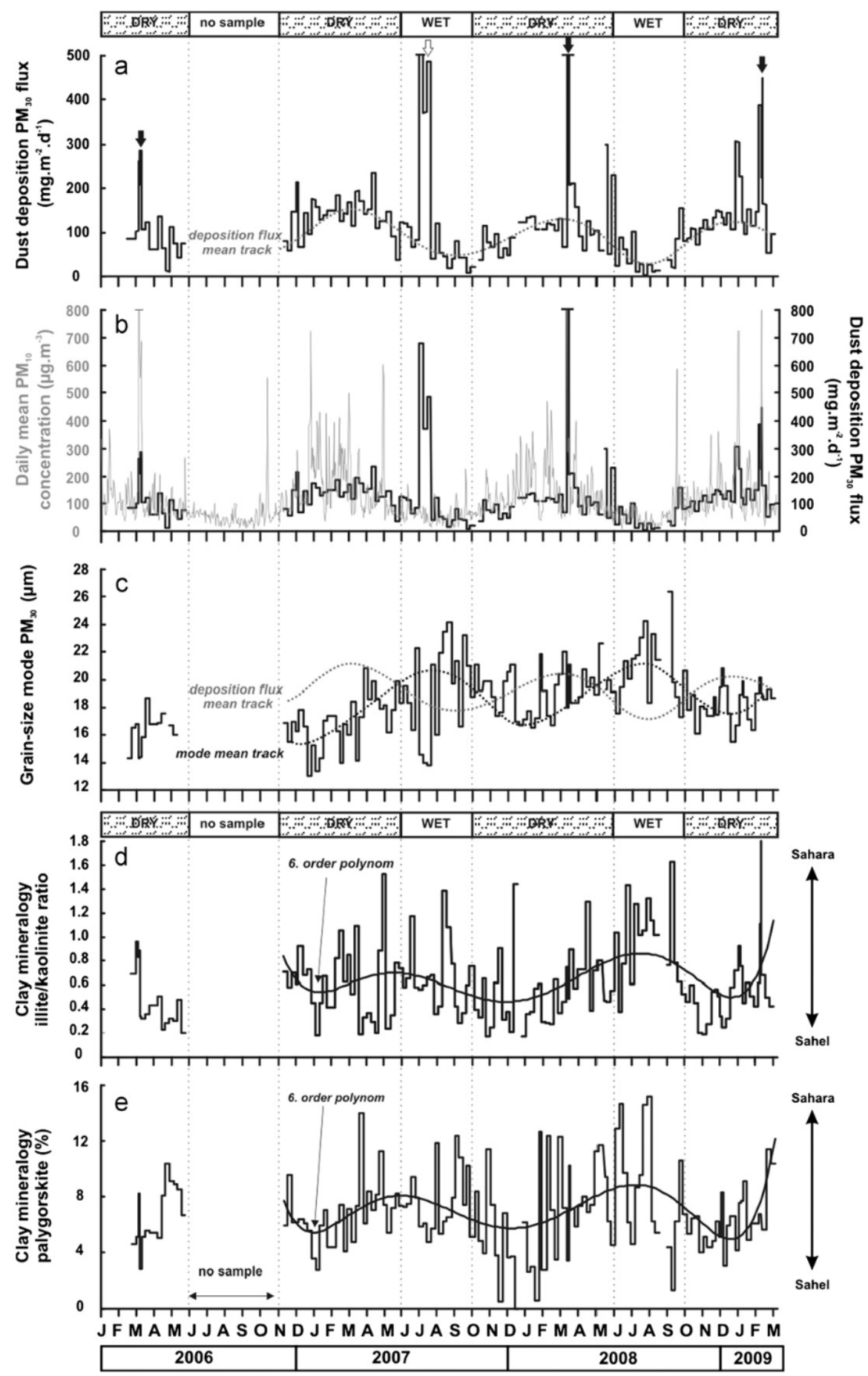

Fig. 1. Mineral dust deposition time-series for the years 2006-2009 at Mbour (Senegal). From top to bottom: total (dry plus wet) dust deposition flux for the $<30 \mu \mathrm{m}$ carbonate-free fraction ( $\mathrm{mg} \mathrm{m}^{-2} \mathrm{~d}^{-1}$; arrows on panel indicate the dry [black] and wet [grey] major depositional events studied in detail); dust deposition flux together with daily mean PM10 concentration (mg m 3; Marticorena et al., 2010); mean modal grain size $(\mu \mathrm{m})$; illite/kaolinite ratio; palygorskite content $(\%)$. 


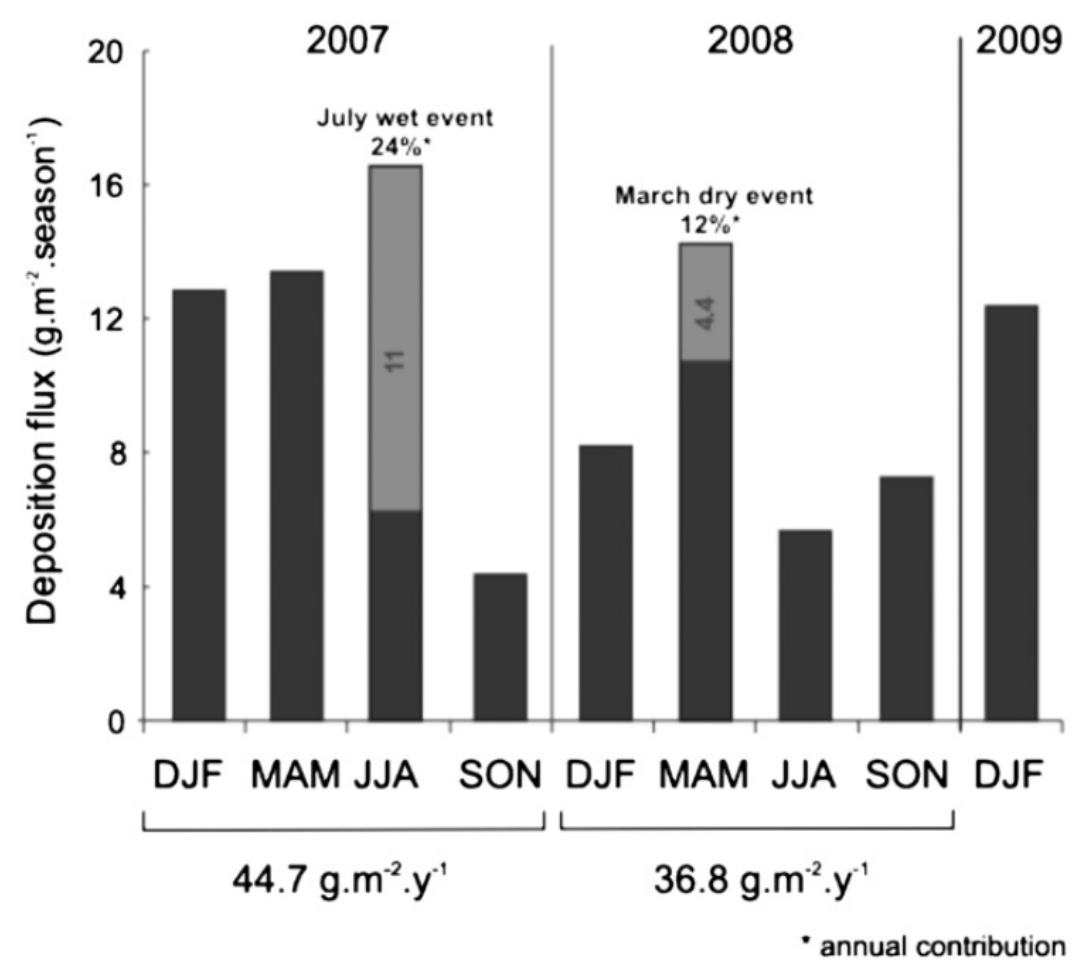

Fig. 2. Total (dry plus wet) seasonal dust deposition yields ( $\mathrm{g} \mathrm{m}$ 2) throughout the period winter 2007 to winter 2009 period. Grey bars represent the contribution of the July 2007 and March 2008 major depositional events. Annual mean dust deposition yields are also provided for 2007 and 2008. 


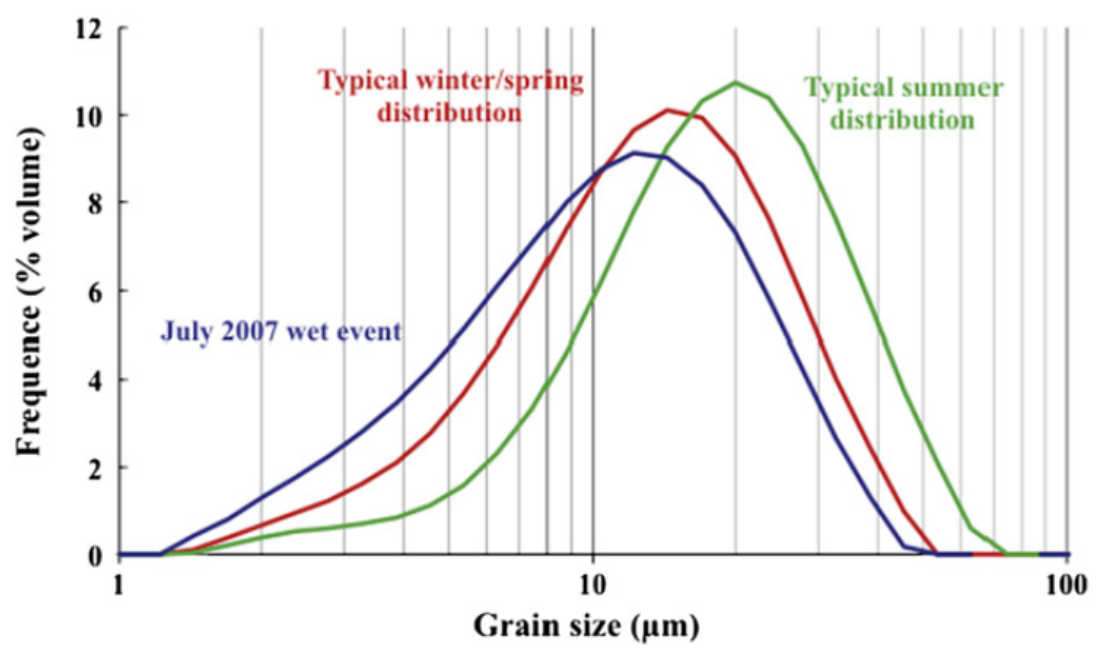

Fig. 3. Seasonal changes in the grain-size distributions of mineral dust deposited at Mbour. The red curve represents a typical winter/spring distribution and the green curve represents a typical summer-season distribution; the blue curve shows the corresponding distribution for the unique large "wet" event collected during our three-year time series (July 2007). The uncertainty on the mean modal values (see Supplementary material), obtained from repeat measurements of standards, is $70.4 \mu \mathrm{m}$. As a result, the observed differences between seasonal mean modal values are significant and well resolved. (For interpretation of the references to color in this figure legend, the reader is referred to the web version of this article.) 

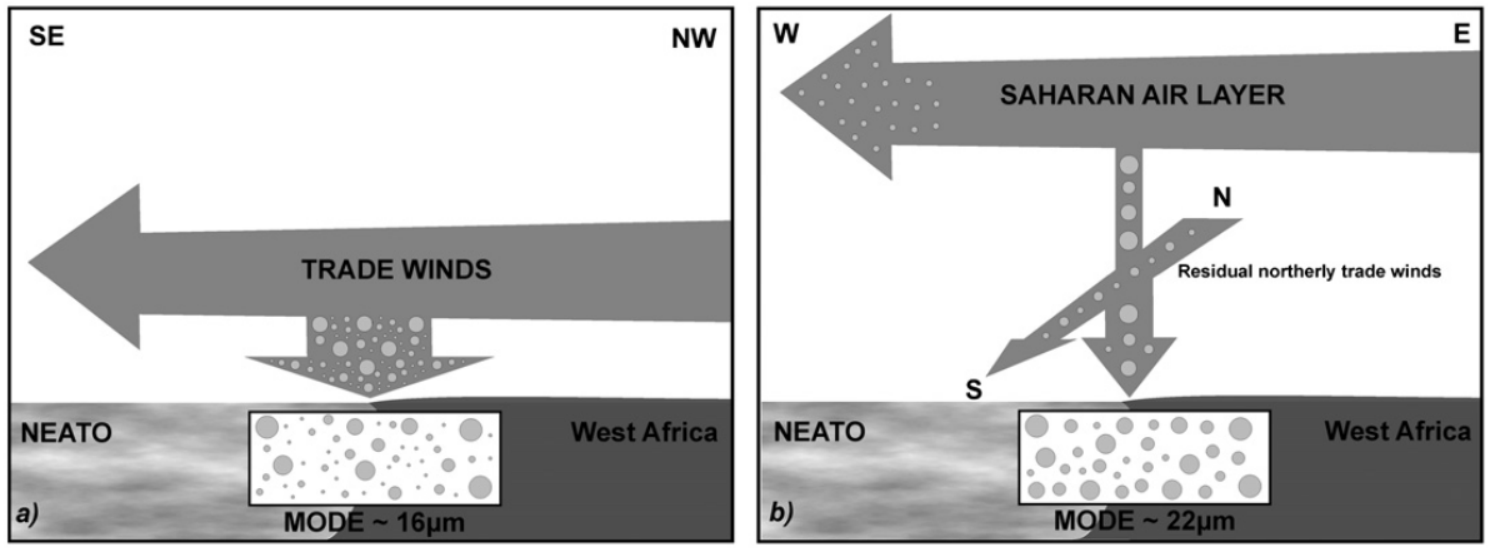

Fig. 4. Schematic representation of the change in the altitude of transport between (a) the winter/spring and (b) the summer seasons along with the associated grain-size fractionation process, as recorded by our dust deposit time series at Mbour. 

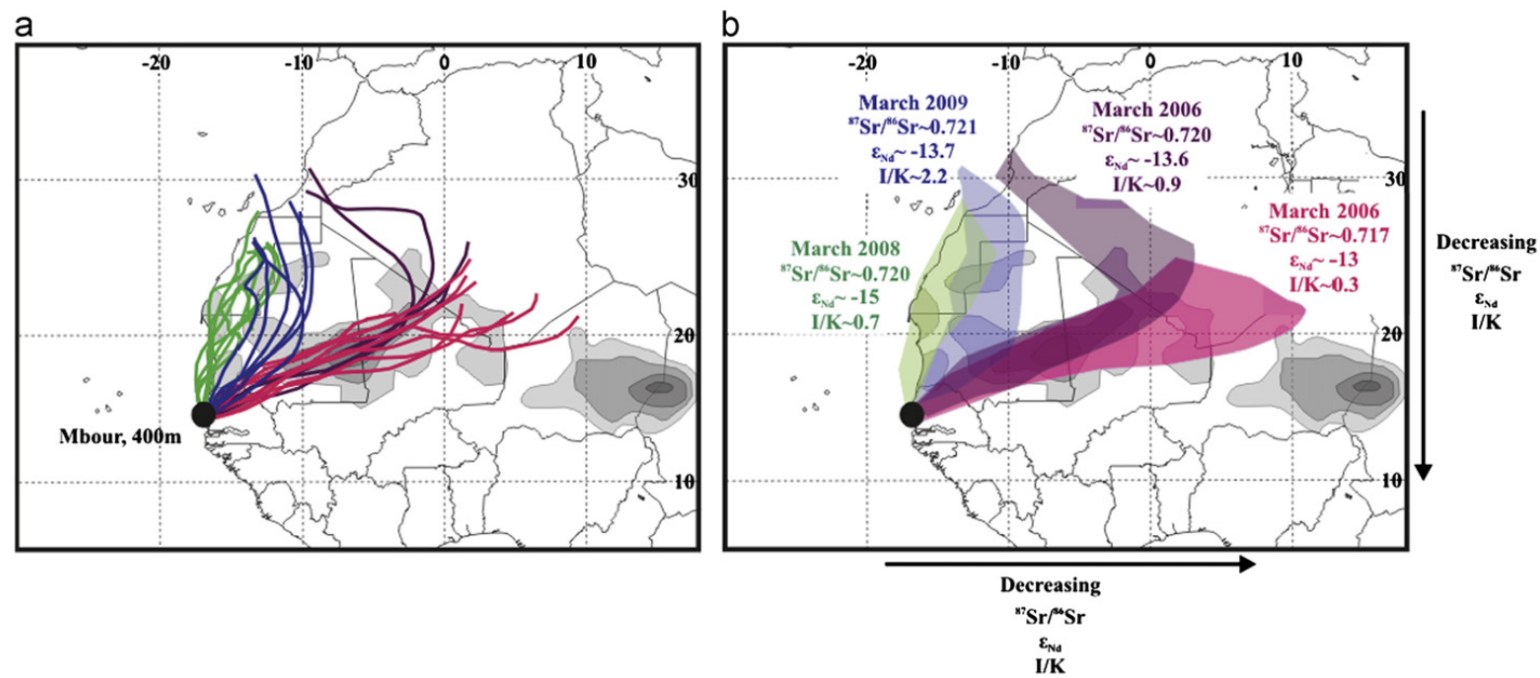

Fig. 5. Background map shows the annual mean Aerosol Index (AI) values 415 from TOMS data (1980-93, 1997-2000; adapted from Goudie and Middleton, 2001). (a) Tri-dimensional air masses back trajectories computed to end at approximately $400 \mathrm{~m}$ AGL above the Mbour station throughout 2006 (purple and pink), 2008 (green) and 2009 (blue) major spring outbreaks. For the March 2006 event, two distinct phases were observed (see Skonieczny et al., 2011, for details). The trajectories' durations vary from 3 days to 6 days depending on the spatial extension of the dust outbreak, as seen on SEVIRI images. Calculations were made using the HYSPLIT model (R.R. Draxler and G.D. Rolph, HYSPLIT (HYbrid Single-Particle Lagrangian Integrated Trajectory) Model, 2011, access via NOAA ARL READY Website http://ready.arl.noaa.gov/ HYSPLIT.php; G.D. Rolph, Realtime Environmental Applications and Display system (READY) Website, http://ready.arl.noaa.gov). (b) Summary of the illite/kaolinite ratio and $\mathrm{Sr}$ and $\mathrm{Nd}$ isotopic compositions obtained for each of the major spring deposition events together with the corresponding sector of provenance of the outbreak (envelopes of back-trajectories as presented in Fig. 5a). (For interpretation of the references to color in this figure legend, the reader is referred to the web version of this article.) 


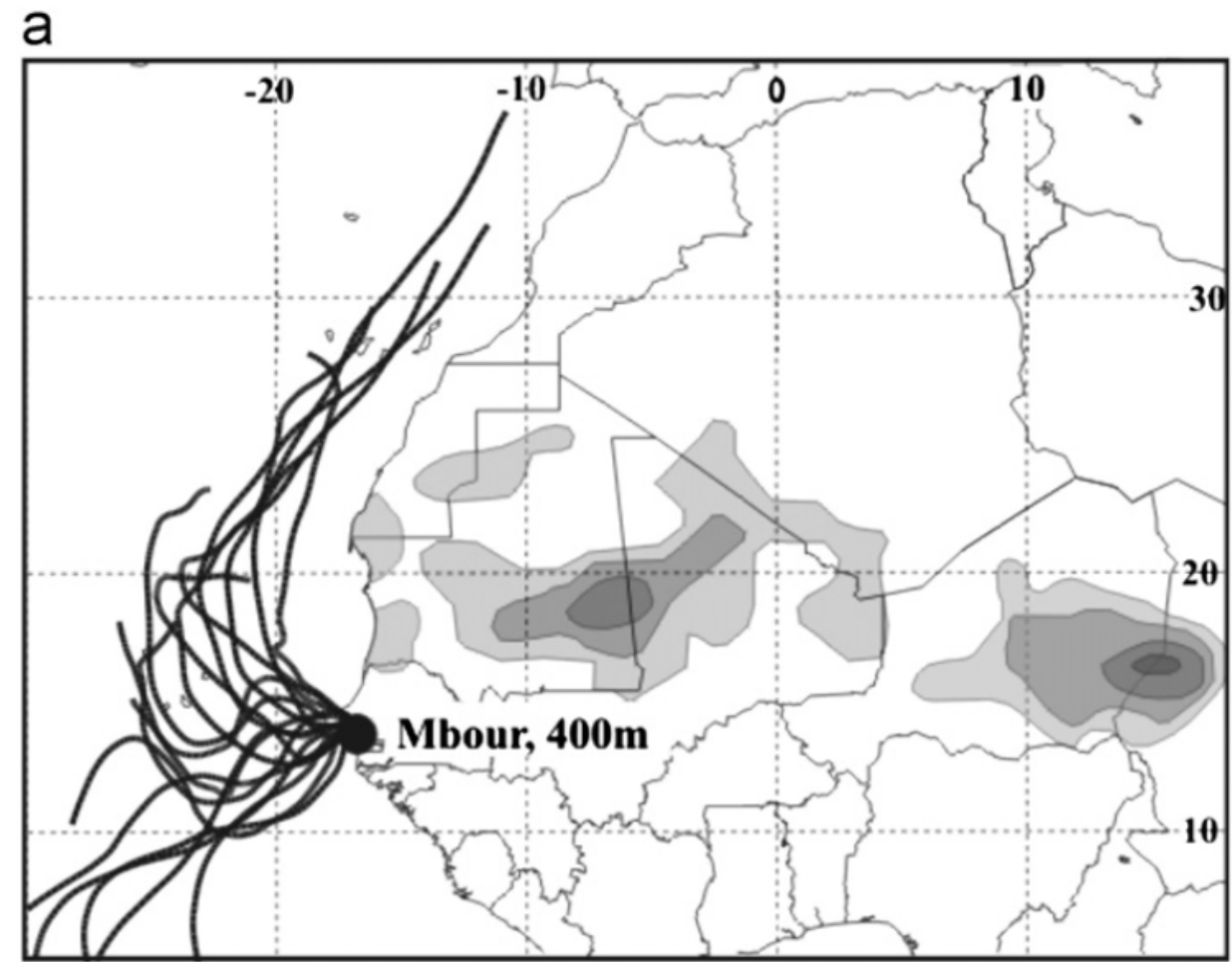

b

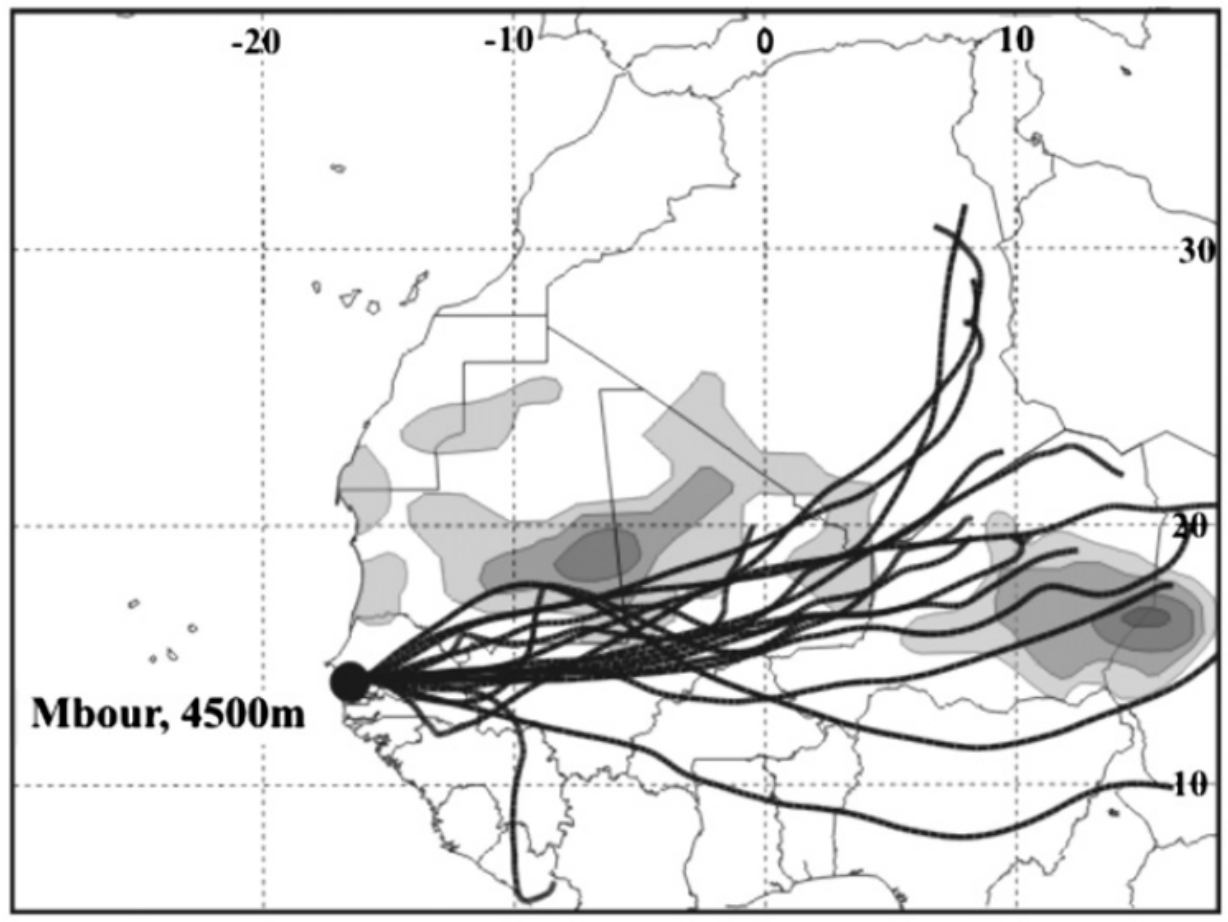

Fig. 6. 4-days tri-dimensional air mass back-trajectories computed to terminate over Mbour at $400 \mathrm{~m}$ AGL (a) and $4500 \mathrm{~m}$ AGL (b) throughout the 13/07-02/08/ 2007 wet period (i.e., corresponding to the major wet depositional event's duration; see Table 1). Background map shows the annual mean Aerosol Index (AI) values 415 from TOMS data (1980-93, 19972000; adapted from Goudie and Middleton, 2001). 


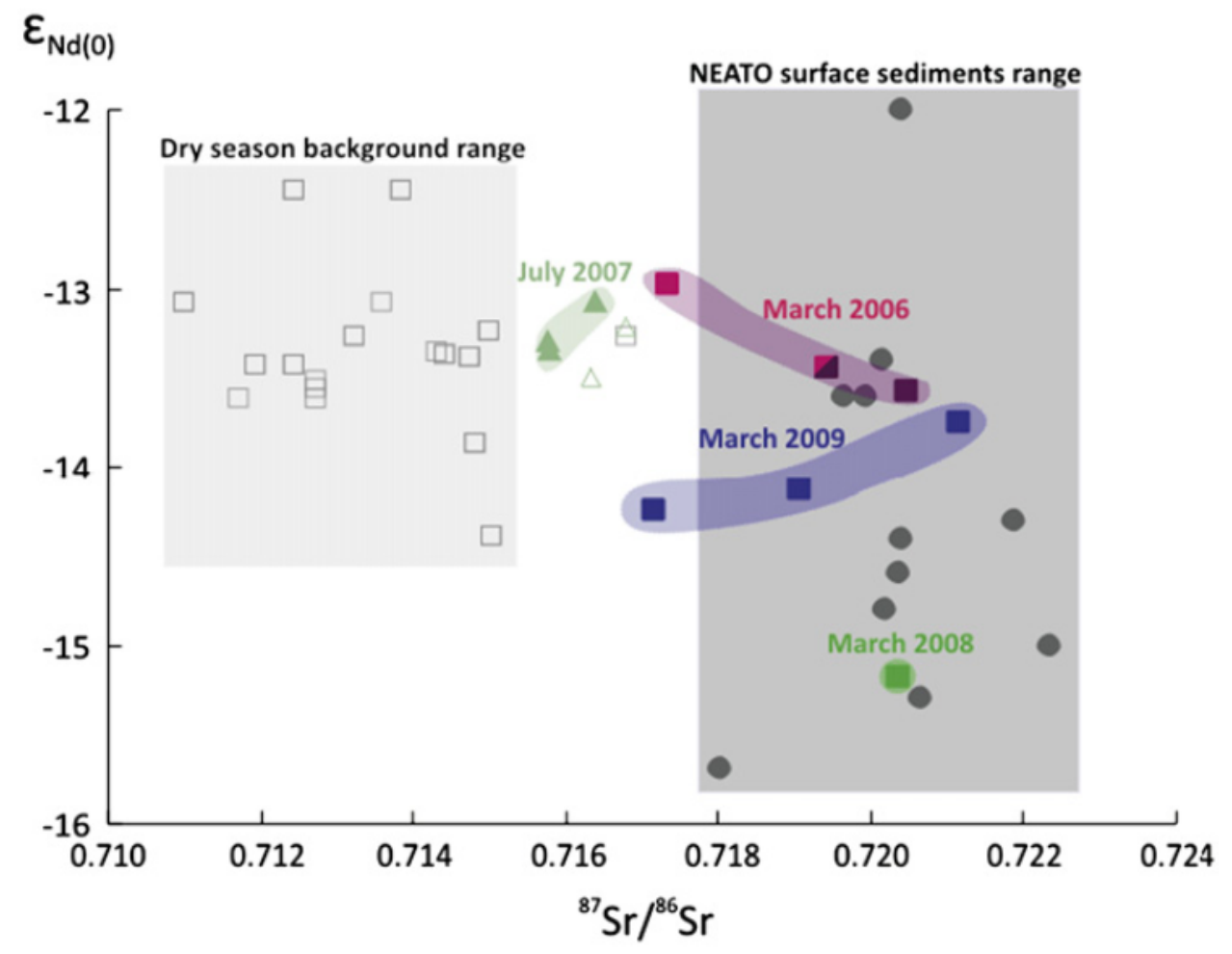

Fig. 7. $\varepsilon_{\mathrm{Nd}}$ vs. ${ }^{87} \mathrm{Sr} /{ }^{86} \mathrm{Sr}$ of dust deposited across some of the major deposition events (including surrounding background values) found in the 2006-2009 time- series (squares and triangles) compared to the isotopic composition of core-top sediment values (i.e., Late Holocene) values from the literature (circles; Grousset et al., 1998; Cole et al., 2009). Samples belonging to the same event (March 2006, March 2008 or March 2009) are contoured, and the color code used for each of these events is identical to the one used for the back trajectories shown on Fig. 5a. (For interpretation of the references to color in this figure legend, the reader is referred to the web version of this article.) 
Table 1

Dust deposition fluxes, grain size modes, clay mineralogy, $\mathrm{Sr}$ and $\mathrm{Nd}$ isotopic compositions, and fresh-water diatom counts during some of the major dry and wet deposition events recorded during the 2006-2009 study period at Mbour (Senegal).

\begin{tabular}{|c|c|c|c|c|c|c|c|c|c|c|c|c|c|c|c|c|}
\hline Sampling start & Sampling end & Deposition & $\begin{array}{l}\text { Mass flux } \\
0-30 \mu \mathrm{m} \\
\left(\mathrm{mg} \mathrm{m}^{-2} \mathrm{~d}^{-1}\right)\end{array}$ & $\begin{array}{l}\text { Grain } \\
\text { size } \\
\text { mode }^{\mathrm{a}} \\
(\mu \mathrm{m})\end{array}$ & $\begin{array}{l}\text { Smectite } \\
\text { (\%) }\end{array}$ & Illite $^{\text {b }}$ & Palygorskite ${ }^{b}$ & Kaolinite $^{b}$ & Chlorite $^{b}$ & $1 / \mathrm{K}$ & $\begin{array}{l}{ }^{87} \mathrm{Sr} /{ }^{86} \mathrm{Sr} \\
\left(\times 10^{-6}\right)\end{array}$ & $\begin{array}{l}{ }^{143} \mathrm{Nd} /{ }^{144} \mathrm{Nd} \\
\pm 2 \sigma\left(\times 10^{-6}\right)\end{array}$ & $\varepsilon_{\mathrm{NA}}(0) \pm 2 \sigma$ & $\begin{array}{l}\text { Hantschia } \\
\text { Amphioxs } \\
\left(10^{6} \mathrm{vg}^{-1}\right)^{c}\end{array}$ & $\begin{array}{l}\text { Aulacoseseira } \\
\text { Gotzeana } \\
\left(10^{6} \mathrm{vg}^{-1}\right)^{c}\end{array}$ & $\begin{array}{l}\text { Diatoms } \\
\text { other taxa } \\
\left(10^{6} \mathrm{vg}^{-1}\right)^{c}\end{array}$ \\
\hline \multicolumn{17}{|c|}{ March 2006 (Skonieczny et al., 2011) } \\
\hline 3/7/2006 16:55 & 3/9/2006 9:20 & Dry & 261 & 14.3 & 33 & 24 & 8 & 27 & 8 & 0.89 & $0.720475 \pm 6$ & $0.511942 \pm 2$ & $-13.6 \pm 0.1$ & 1.96 & 0.39 & 0.39 \\
\hline $3 / 9 / 20069: 30$ & $3 / 10 / 200610: 47$ & Dry & 209 & n.d. & 50 & 17 & 6 & 20 & 7 & 0.84 & $0.719425+6$ & $0.511949+5$ & $-13.4+0.1$ & n.d. $\quad$ ） & n.d. $\quad$ ） & n.d. \\
\hline 3/10/2006 11:01 & 3/13/20069:45 & Dry & 285 & 14.3 & 62 & 8 & 3 & 22 & 5 & 0.35 & $0.717348 \pm 7$ & $0.511973 \pm 4$ & $-13.0 \pm 0.1$ & 0.00 & 2.73 & 0.55 \\
\hline \multicolumn{17}{|c|}{ March 2008} \\
\hline 3/13/2008 10:15 & 3/20/2008 9:55 & Dry & 132 & 20.4 & 29 & 11 & 12 & 31 & 15 & 0.37 & $0.714428 \pm 9$ & $0.511953 \pm 10$ & $-13.4 \pm 0.3$ & 2.08 & 1.04 & 0.00 \\
\hline 3/20/2008 10:20 & $3 / 27 / 200814: 25$ & Dry & 67 & 22.0 & 42 & 11 & 7 & 24 & 15 & 0.46 & $0.711715 \pm 7$ & $0.511940 \pm 4$ & $-13.6 \pm 0.1$ & 0.00 & 0.00 & 0.00 \\
\hline 3/27/2008 14:45 & 3/31/2008 10:35 & Dry & 1150 & 18.0 & 60 & 13 & 4 & 17 & 6 & 0.74 & $0.720365 \pm 5$ & $0.511860 \pm 4$ & $-15.2 \pm 0.3$ & 0.42 & 0.84 & 5.02 \\
\hline 3/31/2008 11:00 & 4/3/2008 8:15 & Dry & 208 & 21.1 & 35 & 13 & 10 & 27 & 15 & 0.49 & $0.712750 \pm 6$ & $0.511943 \pm 4$ & $-13.6 \pm 0.1$ & 0.00 & 2.30 & 0.00 \\
\hline 4/3/2008 8:35 & 4/10/2008 10:20 & Dry & 212 & 18.3 & 38 & 17 & 7 & 19 & 20 & 0.89 & $0.714821 \pm 5$ & $0.511927 \pm 5$ & $-13.9 \pm 0.1$ & 0.65 & 1.94 & 0.00 \\
\hline \multicolumn{17}{|c|}{ March 2009} \\
\hline 2/26/2009 16:20 & 3/2/2009 11:45 & Dry & 105 & 20.2 & 45 & 11 & 7 & 18 & 19 & 0.62 & $0.712749 \pm 5$ & $0.511945 \pm 11$ & $-13.5 \pm 0.4$ & n.d. & n.d. & n.d. \\
\hline 3/2/2009 12:05 & 3/4/20099:15 & & 106 & 19.0 & & & 5 & & 15 & 1.11 & $0.717165 \pm 6$ & $0.511908 \pm 8$ & $-14.2 \pm 0.2$ & & n.d. & n.d. \\
\hline $3 / 4 / 20099: 38$ & $3 / 5 / 200910: 25$ & Dry & 465 & 18.9 & 39 & 28 & 6 & 13 & 15 & 2.23 & $0.721169 \pm 6$ & $0.511933 \pm 5$ & $-13.7 \pm 0.1$ & n.d. & n.d. & n.d. \\
\hline $3 / 5 / 200911: 05$ & $3 / 6 / 20098: 25$ & Dry & 270 & 20.8 & 55 & 14 & 4 & 17 & 10 & 0.80 & $0.719064 \pm 5$ & $0.511916 \pm 5$ & $-14.1 \pm 0.1$ & n.d. & n.d. & n.d. \\
\hline 3/6/2009 8:50 & $3 / 7 / 2009$ 10:25 & Dry & 19 & 19.0 & 21 & 30 & 11 & 17 & 21 & 1.77 & $0.716800 \pm 7$ & $0.511957 \pm 11$ & $-13.3 \pm 0.3$ & n.d. & n.d. & n.d. \\
\hline \multicolumn{17}{|l|}{ July 26} \\
\hline 7/5/2007 10:35 & $7 / 12 / 20079: 45$ & Wet & 84 & 22.2 & 42 & 14 & 8 & 24 & 13 & 0.58 & $0.716801 \pm 4$ & $0.5119588 \pm 11$ & $-13.2 \pm 0.3$ & 1.76 & 0.88 & 0.00 \\
\hline $7 / 12 / 2007$ 10:05 & $7 / 19 / 2007$ 10:55 & Wet & 679 & 14.6 & 43 & 14 & 6 & 26 & 12 & 0.56 & $0.716406 \pm 6$ & $0.5119672 \pm 8$ & $-13.1 \pm 0.2$ & 0.19 & 1.16 & 1.73 \\
\hline $\begin{array}{l}7 / 19 / 200711: 20 \\
7126 / 200711\end{array}$ & $\begin{array}{l}7 / 26 / 2007 \\
10: 55\end{array}$ & Wet & 373 & 14.0 & 46 & 13 & 6 & ${ }_{25}^{21}$ & ${ }_{13}^{14}$ & 0.60 & $0.715780 \pm 5$ & $0.5119556 \pm 10$ & $-13.3 \pm 0.2$ & 0.24 & 1.19 & 1.43 \\
\hline $\begin{array}{l}7 / 26 / 200711: 20 \\
8 / 2 / 200711: 45\end{array}$ & $\begin{array}{l}8 / 2 / 200711: 10 \\
8 / 9 / 200711: 15\end{array}$ & $\begin{array}{l}\text { Wet } \\
\text { Wet }\end{array}$ & $\begin{array}{r}486 \\
40\end{array}$ & $\begin{array}{l}13.8 \\
21.0\end{array}$ & $\begin{array}{l}41 \\
39 \\
39\end{array}$ & $\begin{array}{l}16 \\
18\end{array}$ & $\begin{array}{l}5 \\
6\end{array}$ & $\begin{array}{l}25 \\
26 \\
\end{array}$ & $\begin{array}{l}13 \\
11\end{array}$ & $\begin{array}{l}0.66 \\
0.69\end{array}$ & $\begin{array}{l}0.715789 \pm 4 \\
0.71635 \pm 4\end{array}$ & $\begin{array}{l}0.5119526 \pm 10 \\
0.519455+12\end{array}$ & $\begin{array}{l}-13.4 \pm 0.22 \\
-135+03\end{array}$ & $\begin{array}{l}0.32 \\
0.00\end{array}$ & $\begin{array}{l}0.97 \\
0.00\end{array}$ & 0.65 \\
\hline & & & & & & & & & & & & & & & & 0.00 \\
\hline
\end{tabular}

n.d: no data.

${ }^{a}$ analytical error less than $0.4 \mu \mathrm{m}$.

${ }^{\mathrm{b}}$ analytical error less than $5 \%$.

${ }^{\mathrm{c}} 10^{6}$ valves per gram of sediment. 